\title{
The Contribution of Character Strength to the Hotel Industry Employees' Performance in Bandung
}

\author{
Dewi Sartika and Oki Mardiawan
}

\begin{abstract}
The level of competition in hotel industry is very high. The euphoria of hotel businesses in Bandung, makes the need of human resources escalate as well. Therefore, all hotel must increase their facilities and services so that they are chosen as the main alternative for the customers. The parameter in the succes of giving service is 'service quality'. This research intended to describe the correlation and contribution of character strengths variable to the employee's performance. Character strength theory developed by Seligman was employed in this study and Performance theory develop by Chambell. The method used was correlation method, and multi regression technique. It was revealed that there were 5 dominant characters found in the employees. They were integrity, gratitude, fairness and kindness, and those are also called signature strength. Signature strength altogether don't give significant contribution to performance, character strengths give very small contribution to performance, which means the other is determined by other variables.
\end{abstract}

Index Terms-Character strength, performance, hotel employees.

\section{INTRODUCTION}

The prospect of hotel business in Indonesia is declared promising, Indonesia become the international investors' favorite location. A survey result released in the last August by Trip Advisor, a worldwide traveling site, put Indonesia as the most wanted place by investors followed by Russia, Brazil and the USA, the three countries had been dominated the world's hotel business [1].

Bandung is the the capital city of West Java province. This city is $140 \mathrm{~km}$ to the southeast from Jakarta and is the third biggest city in Indonesia after Jakarta and Surabaya by its population the population of Bandung in 2014 was $2,470,802$. Bandung is also called a historic city, the capital of Asia Africa Conference in 1955. It is the place where the first engineering institute in Indonesia (Technische Hoogeschool te Bandoeng - TH Bandung, now Institut Teknologi Bandung - ITB) stands. Besides, in the era of independence struggle, Bandung was the host city of AsiaAfrica conference in 1955 [2].

Bandung has got some soubriquets as the city of education, commerce, government and tourism. Bandung has become an attraction not only for the people from West Java but also from the entire Indonesia and internationally, Bandung is quite well-known.

"In the meantime Bandung has been known as a major

Manuscript received December 10, 2015; revised March 3, 2016.

D. Sartika and O. Mardiawan are with the Faculty of Psychology, Islamic University Bandung, West Java, Indonesia (e-mail dsartk@yahoo.com). tourist destination for travel and education". Even Bandung would be enacted as one of the historic tourism sites in the world since it is known by the Asia- Africa countries as the inspiration of independence, said the former Vice Mayor, Ayi Vivananda, when he set off a cultural parade in the occasion of Asia- Africa 57th commemoration [3]. Therefore, necessitate of hotel services becomes a priority. Because hotel can provide not only a comfortable accommodation with good facilities, but it is also able to introduce the culture of West Java that is well-known for its hospitality [2].

The level of competition in hotel industry is very high. These days in Bandung, there are already 523 hotels that consist of 5 star to 1 star hotel. It is automatically increased the level of competition among the hotel. Therefore, all hotel must increase their facilities and services so that they are chosen as the main alternative for the customers. Hotel business is hospitality industry, it is very important ensure to all hotel to delivered their promise to give an excellent service to their guest. Delivering excellent services will depend on the human, as the person who will serve the guest. That is why the increase of the hotel number will also increase the needs of human recources. The employees are required to keep increasing their skills and abilities, creativity and also customer service orientation so that they could attract the customers and compete to keep their existence in hotel industry. Besides being demanded to think creatively, work hard, be innovative and be oriented to customer satifaction, the more important aspect is the strength and patience in dealing with the customers whom revered to as the 'king', and ready to accept complaints, and stand by to fulfil various requests, being critisized, and compared with service in other hotels, and to keep giving the best service while under pressure [2].

The competition within the hotels, is not only about attracting the guest but it is also effecting to the employee. The increase of a hotel number, it will increase the demand of the employee as well. Meanwhile the sources (institution) is remain the same. That is why employees turn over in Bandung is quite high in all level. The reason of employee's choose to move from one hotel to another hotel mostly to find a better work environment and better pay. They just do it for trial, because they do not know the working environment at the new hotel. They are not looking for job satisfaction yet. That is why when they felt not like it, they can easily find another hotel and move. At the end it will affected to the service delivery of the hotel, because hotel Human Resources department have to trained their new employee and difficult to have a consistent service if the employee keep changing.

The parameter in the succes of giving service is 'service 
quality' which is tied to: tangibles, reliability, responsiveness, competence, courtesy, credibility, security, access, communication, and customer understanding [4].

Therefore it is not easy to get resources that could really qualify all the mentioned service qualities. In an interview with a General Manager of a 5-star hotel located in Northen Bandung, it is pictured that searching for human resources that qualify a real hotel service is quite difficult. Employee reqruitments, especially for guest contact division, is really strict. Because they act as a 'gate' or 'main door' that can give an impression to the customer. The qualification for employees, especially in guest contact units, is to have a fun personality, able to make others happy, friendly, and able to help other people sincerely. Those things are required in a hotel employee, so that he can work optimally. As a hotel employee, it is a must to give prime service, and must be followed by a pleasant and happy feeling. Tied by the fun personality as a requirement, being able to bring joy to others and having a high service 'soul', are mentioned in the Positive Psychology as one of the character strengths [5]. These days, a more human-oriented kind of Positive Psychology is developing, where humans are seen as an individual with positive characteristics that can be developed so they can achieve greatness and satisfaction emotionally, be it in their work or their lives.[5]

The researcher is interested to do a series of reasearch in the hotel service field, considering that hotels are one of the companies that work in the field of service, which has the main duty to give service to customers, so that they will feel comfortable, happy and feel at home, when they use the service.

Furthermore, the researcher also wants to find out if the characteristic power will also give an impact to individual work. With such, the researcher is also interested to find out the signature strength of employees who work in the hotel service. Are there any signature strength that became a trademark for those group of employees, especially in Bandung? And also, how much does that character impact their daily work, in this aspect, their service performance. If a dominant character that affects the work has been found, next a training module will be made to develop that characteristic strength which is needed to improve their performance.

Peterson and Seligman, introduce character strength as one of the areas of investigation in positive psychology. Character strength is a positive trait that consists of good character. It is a quality in an individual that makes him or her seen morally well. That positive character can be seen from their feeling, thought and individual behavior.[5]

Seligman also introduce the term 'signature strength', it is somebody's exceptional character. According to him, an individual can accomplish success and the deepest emotional satisfaction by employing and developing his/ her signature character in his/ her daily life instead of fixing his/ her weaknesses. Signature strength is said as a conscious strength and often being shown in daily basis. The use of signature strength will make that individual feel happy and more prepared in facing activities.

There are a lot of definitions of performance. According to Maier (1976), job performance means as an accomplishment of a worker in doing his work. While according to Ivancevich (1977), job performance could mean an outcome that happened as a function from ability and desire. And Richard Henderson (1980) suggest that, "Performance is a measure of the output of a jobholder that contributes to productivity". So, from those definitions can be concluded that performance is a work result that is shown by the worker which is resulted from ability and desire which becomes a success measurement in his job and contributed to productivity.

Meanwhile, according to Cambel (Cambel et al, 199) performance is what an employee does to get a good result. Performance is not defined by what he does but with assessment and evaluation to the process.[8]

The concept of performance must differentiate the aspect behavior and outcome from someone's work.

Statement of Problem To make the study clear, the problems above can be explained in the following problem statements. "How is the description of the character strength described as the signature of the employees in the hotel industry in Bandung?" and "Among the five signature strengths mentioned, which one gives the most significant contribution to their performance?"

The aim of this study is to gain an empirically clear description about the signature strengths of the hotel employees in Bandung. Furthermore, the study intends to find which strength gives the most significant contribution to their performance.

Significance of the Study, Referring to the Positive Psychology principal that everyone has potentials to be developed, this study is determined to discover the description of the signature strengths of the hotel employees that have significant contribution to their performance accomplishment. The strengths can be further constructed as 'a model' to formulate new signature strength development programs for hotel employees and others to generate accomplishments (the best performance) and emotional satisfaction.

\section{METHOD}

The method employed was correlation method. It was used to find out the correlation and contribution of character strengths variable to the employee's performance.

There were two measurements used in this study. The first was the VIA Survey of Character Strengths. It is a scale developed by Martin E. P Seligman to measure positive characters that individuals have. It measures the 5 most dominant (the highest) characters out of 24 that are called signature strengths [5] The second scale was the performance scale. This is a working assessment scale developed based on the concept by Cambell et.al that measures task performance and contextual performance that is adjusted to the assessment of hotel employees. The scale was presented in the form of rating scale. It was completed by employers to assess their employees. [6]

And, the aspects used as the performance assessment are also based on the service quality criteria by Valarie A. Zeithaml at all. The criteria are (1) task performance; communication, reliability, responsiveness, competence, and (2) contextual performance; tangible, courtesy, access and understanding the customer. [7] 
The populations of this study were employees and operational supervisors of 4 and 5 star hotel in Bandung. They were chose by using cluster sampling. This technique enables random choosing and they became only 3 hotels. Multi regression technique was then employed to see the contribution of characters strength to the employees' performance.

\section{RESULT AND DISCUSSION}

Based on the data processing of each subject, the five highest ranks of Signature Strength found in the subjects (hotel employees) is revealed as follows;

TABLE I: PROFILE SIGNATURE STRENGTH HOTEL EMPLOYEES

\begin{tabular}{|c|c|}
\hline Ranking & Signature Strength \\
\hline 1 & Integrity \\
\hline 2 & Gratitude \\
\hline 3 & Hope \\
\hline 4 & Fairness \\
\hline 5 & Kindness \\
\hline
\end{tabular}

Table I describes the signature strength profile for hotel employees as follows: integrity, gratitude, hope, fairness and kindness.

TABLE II: PRofile Signature StRENGTH MANAGERILA Hotel EMPLOYEE

\begin{tabular}{|c|c|}
\hline Ranking & Signature Strength \\
\hline 1 & Gratitude \\
\hline 2 & Citizenship \\
\hline 3 & Integrity \\
\hline 4 & Vitality \\
\hline 5 & Hope \\
\hline
\end{tabular}

Table II is the signature strength profile for hotel employees at managerial level, which are the following: gratitude, citizenship, integrity, vitality and hope.

TABLE III: PROFILE SIGNATURE STRENGTH NON MANAGERIAL HOTEL EMPLOYEES

\begin{tabular}{|c|c|}
\hline Ranking & Signature Strength \\
\hline 1 & Integrity \\
\hline 2 & Gratitude \\
\hline 3 & Hope \\
\hline 4 & Fairness \\
\hline 5 & Kindness \\
\hline
\end{tabular}

Table III is the signature strength profile for hotel employees at non managerial level (staff), and they are as follows: integrity, gratitude, hope, fairness and kindness.

TABLE IV: PROFILE SIGNATURE STRENGTH GOOD PERFORMANCE HOTEL EMPLOYEE

\begin{tabular}{|c|c|}
\hline Ranking & Signature Strength \\
\hline 1 & Gratitude \\
\hline 2 & Integrity \\
\hline 3 & Kindness \\
\hline 4 & Hope \\
\hline 5 & Fairness \\
\hline
\end{tabular}

Table IV above presents signature strength profile for hotel employees with good performance as follows: gratitude, integrity, kindness, hope and fairness.

Refer to Fig. 1 above, from all respondent the performance appraisal had shown that: $16 \%$ are Very Good performance, $48 \%$ are Good, $30 \%$ are Average and $6 \%$ are Low.

\section{PA all Employee's}

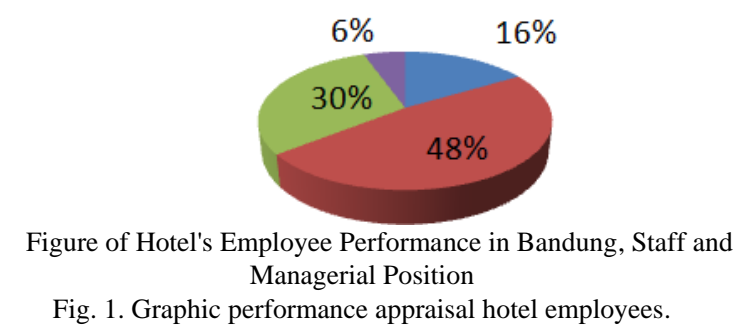

\section{PA Managerial}

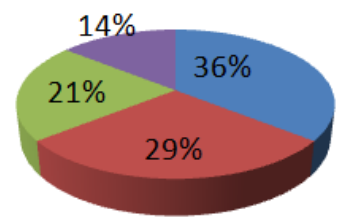

Figure of Hotel's Employee Performance in Bandung, Managerial Position

Fig. 2. Graphic performance appraisal managerial hotel employees.

Refer to Fig. 2 above, from employees at managerial level has shown that: $36 \%$ employee's had very good performance, $29 \%$ are Good, $21 \%$ are Average and $14 \%$ are Low.

\section{PA Non-Managerial}

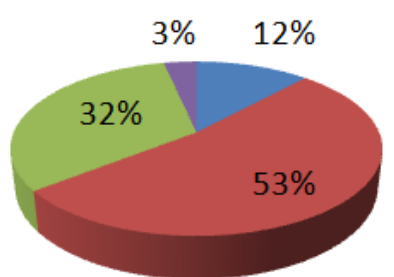

Figure of Hotel's Employee Performance in Bandung, Staff Position Fig. 3. Graphic performance appraisal hotel employees.

Refer to Fig. 3 above, from employee's at non managerial level (staff) has shown that: $12 \%$ employee's had Very Good performance, $53 \%$ are Good, $32 \%$ are Avarage and 3\% are Low.

Regression result between Signature Strenght and Hotels Employee Performance in Bandung the sigma is $=0.303$. $\mathrm{HO}$ is rejected if $\operatorname{sig}<\alpha$. Because the $\operatorname{sig}>0.05, \mathrm{HO}$ is accepted. It means there are no significant contribution from Signature Strenght to Employee Performance. Because there are no significant contribution from the 5 Signature Strenght together, no need to analize the contribution of each Character further. $\mathrm{R}$ square $=0.084$, it means that contribution of Signature Strenght (Integrity, Kindness, Fairness, gratitude dan Hope) all together to the performance is only $8.4 \%$, in the other hand $91.6 \%$ are influenced by other vaiable.

Regression result between Signature Strenght and Hotels Employee Performance in Bandung at Managerial level, the sigma is $=0.194$. HO is rejected if $\operatorname{sig}<\alpha$. Because the sig $>0.05, \mathrm{HO}$ is accepted. It means there are no significant contribution from Signature Strenght to Employee Performance at Managerial Level. Because there are no 
significant contribution from the 5 Signature Strenght together, no need to analize the contribution of each Character further. $\mathrm{R}$ square $=0.547$, it means that contribution of Signature Strenght (Integrity, Kindness, Fairness, gratitude and Hope) all together to the performance is only $54.7 \%$, in the other hand $45.3 \%$ are influenced by other variable.

Regression result between Signature Strenght and Hotels Employee Performance in Bandung at Non Managerial level, the sigma is $=0.066$. HO is rejected if $\operatorname{sig}<\alpha$. Because the sig $>0.05, \mathrm{HO}$ is accepted. It means there are no significant contribution from Signature Strenght to Employee Performance at Non Managerial Level. Because there are no significant contribution from the 5 Signature Strenght together, no need to analize the contribution of each Character further. $\mathrm{R}$ square $=0.173$, it means that contribution of Signature Strenght (Integrity, Kindness, Fairness, gratitude and Hope) all together to the performance is only $17.3 \%$, in the other hand $82.7 \%$ are influenced by other variable.

The highest average of every character strength is signature strength of the hotel employees in Bandung. It is dominant character strength attached, realized and often shown in daily life (Seligman, 2004). By doing their jobs relying on the signature strength, individuals will feel comfortable and are able to maintain a job.

Based on the research, the profile of signature strengths found in the hotel employees in Bandung were integrity, gratitude, hope, fairness and kindness. Integrity meant they were able to perform their job well because of honesty and ability to show themselves they way they were genuine, without pretending. Integrity meant that the behaviors they showed was always consistent with the values they believe. They were able to treat people wholeheartedly, be responsive to others' need and help them with their need. In hotels, as services providers, this becomes so important since their attitudes and behaviors will affect the customers directly. Gratitude and hope are character strengths tie the universe and its creator. They have strength to apprehend and be grateful for good things they have ever had and always make time to thank all the people they consider meritorious. By having gratitude strength, employees become more accepting and have more positive emotion in performing their duties. Likewise Hope, it is an optimistic feeling in viewing future. By having this strength, they would always try and believe that their efforts would turn as they expected. They hoped for the best for their future. Employees with fairness would treat customers equally, either internal or external customers. All interests are the same and they all have to be taken care of. They didn't let their personal feeling cloud their objectivity by involving others. They would always implement the rules and keep them as things to be enforced and applied to every individual. With this character strength, a hotel employee will do his work according to the moral value that he follows. With such, he will create a working environment in which he could work peacefully. The last one is kindness character, this character strength is the huge tendency to always do good for other people, and to take care of other people. This is really tied to hotel employees who work in service division. An employee with kindness character strength will help and give services to customers with pleasure. He did this not just because its a job that he has to do, but also because he has a helpful personality, to serve and help others. Therefore, doing service, is not considered as a burden, but as something fun to do. The customer who get his service will also feel this. Empathy and sympathy are important components in kindness.

Based on the multi regression analysis, 5 greatest character strength represented by the signature strengths of hotel employees, which are integrity, gratitude, hope, fairness and kindness don't connect significantly to performance. the reason is that those 5 strengths only give small contributions $(8,4 \%)$ to performance. So, the highs and lows of the performance only determined by $8,4 \%$ of the signature strengths, meanwhile, the other $92,6 \%$ is determined by other variables. When those 5 strengths together make little contribution to performance, then based on basic concept of statistics, it can be said that we don't have to calculate the contribution from each strength to performance. according to Maier (1976), job performance means the success of an employee in doing work. While Ivancevich (1977) said that job performance is an outcome that happens as a function of ability and desire. So from those definitions, it can be implied that performance is the work result that is shown by an employee as the result of his ability and desire which becomes a parameter of his success in doing hus work that contributed to productivity.

"Individual performance is a measurement of employees achievement in performing their job". At least there are 3 (three) main factors that affect performance which are individual factor (work skill), work effort (the will to work), and organizational encouragement (the chance to work]. The individual factor alone is quite wide, besides work skill, there are also interests, motivation, and also personality[8]. But based from the research result, the character factor contributed really small to performance, there are a lot of other factors that determines the performance, for example, from the individual factor itself, there are working ability, working motivation, interests, working satifaction, desire, or the working effort, and organizational encouragement. Meanwhile Robin said that the character /personality factor in fact doesn't directly affect perormance, because, basically, the character/ personality factor affects more to working adaptation compared to performance. Therefore, it is understandable that the contribution of character strengths to performance is really small.

\section{CONCLUSION}

Based on the result that was gathered from data processing and study of 73 Hotel employees, it can be concluded as follows:

1) The Character strength profile pictured as signature strengths in a hotel employee are: Integrity, Gratitude, Hope, Fairness, and Kindness

2) The Signature Strength profile in a good hotel employees are Gratitude, Integrity, Kindness, Hope and fairness.

3) Signature strength altogether don't give significant contribution to performance, character strengths give very small contribution $(8,4 \%)$ to performance, which 
means the other $91,6 \%$ is determined by other variables.

Refer to the conclusion, the are several suggestion as follows:

1) Kindness Character, with characteristic of: kind of heart, concern with other needs and willing to help others are reflected to the employee with Good performance, because of that, Kindness Character can be develop to the employee with Low Performance.

2) At all employee's, Managerial or Non Managerial, for employee's with Good performance, there are 3 character that always on high rank. There are: Gratitude, Integrity and Hope. This three character can become a character strenght model to all hotels employee's in bandung. This three character can be trained and developed to all new employees or student who is going to work at the hotel business.

3) Because Character Strenght has not contribute signifincantly to the performance in this research, there can be a new research that is designed to find other variable together with the character strenght, that can influence to performance, so we can see the direct or indirect influence of other character strenght to the performance.

\section{REFERENCES}

[1] Smart property Indonesia. (2012). Pertumbuhan Bisnis hotel di Indonesia eingkat tajam, kalahkan A,arika Serikat. [Online]. Available: http://samrtproperti wordpress.com.2012/12/05 Pertumbuhan-bisnis-hotel-di-indonesia-meningkat-tajam-kalahkanAmarika-Serikat/

[2] S. Dewi and M. Oki, The Contribution Character Strength to the Organizational Commitent at 4 and 5 star Hotel in Bandung City, 2013.

[3] ROL. (2012). Bandung Incar Status Kota Wisata Sejarah. Dunia. [Online]. Available: http://www.republika.co.id/berita/nasional/umum/12/04/22/m2vbafbandung-incar-status-kota-wisata-sejarah-dunia
[4] S. Benjamin and W. S. Susan, Service Quality, Research Perspectives, Thousand Oaks, California 91320, Sage Publication, Inc.

[5] W. C. Compton, 2005, An Introduction to Posotive Psuchology, Thomson Wadsworth, Belmont, USA, 2004

[6] S. Sabine, Psychological Management of Individual Performance, John Wiley \& Sons, Ltd, 2002.

[7] A. Z. Valerie, P. A. Berry, and L. Leonard, Delivering Quality Service, Balancing Customer, Perceptions and Expectations, The Free Press A Division of Macmillan, 1990.

[8] Brahmasari, I. A. D. Suprayetno, and Agus. (2008). Pengaruh Motivasi Kerja, Kepemimpinan dan Budaya Organisasi terhadap Kepuasan Kerja karyawan serta dampaknya pada Kinerja perusahaan. [Online]. Available: http://Jurnal management dan kewirausahaan/journal database.info/articles/pengaruh motivasikerja-kepemimpinan.html

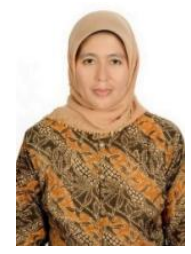

Dewi Sartika was born in Bandung, in 1965. She earning her bachelor degree of psycology in 1991 at Bandung Islamic University, then she continued to her master of science in psychology, in 2003 at Padjajaran University and completing her doctor program of industry psychology at Padjajaran University.

She works as a psychology lecturer, at Bandung Islamic University. She teaches psychometry, research methods, career guidance, graphic test, and psychology interview. Besides teaching, she is active as a speaker in some events such as talk show about education and development and marriage problems in locally private TV station, speaker in seminar regarding counseling and guidance as well as marriage problems.

She is a member in Indonesian Psychology Association (HIMPSI), Industry and Organization Psychology Association (APIO) and Indonesian Developmental Psychology Association (APPI).

Oki Mardiawan was born in Bandung August in 1979. She finishing her bachelor of psychology at the Bandung of Islamic university in 2004 Subsequently she completed magister program of industrial and organizational psychology at Padjadjaran University in 2007.

Currently activity as a lecturer at psychology department in Bandung of Islamic University and teaches courses in organizational psychology, organizational management, personnel psychology, social psychology and psychometrics. research interest in the field of industrial and organizational psychology, social psychology and educational psychology. 